\title{
Bovine lactoferrin and Crohn's Disease: A case study
}

\begin{tabular}{|r|l|}
\hline Journal: & Biochemistry and Cell Biology \\
\hline Manuscript ID & bcb-2016-0107.R2 \\
\hline Manuscript Type: & Article \\
\hline Complete List of Authors: & $\begin{array}{l}\text { Alexander, David; Nagoya City University, Nanotoxicology Project } \\
\text { Iigou, Masaaki; Nagoya City University, Nanotoxicology Project } \\
\text { Abdelgied, Mohamed; Nagoya City University, Nanotoxicology Project; } \\
\text { Nagoya City University Graduate School of Medical Sciences, Department } \\
\text { of Experimental Pathology and Tumor Biology; Beni Suef University, } \\
\text { Department of Forensic Medicine and Toxicology } \\
\text { Ozeki, Keiji; Nagoya City University Graduate School of Medical Sciences, } \\
\text { Department of Gastroenterology and Metabolism } \\
\text { Tanida, Satoshi; Nagoya City University Graduate School of Medical } \\
\text { Sciences, Department of Gastroenterology and Metabolism } \\
\text { Tatashi, Joh; Nagoya City University Graduate School of Medical Sciences, } \\
\text { Department of Gastroenterology and Metabolism } \\
\text { Takahashi, Satoru; Nagoya City University Graduate School of Medical } \\
\text { Sciences, Department of Experimental Pathology and Tumor Biology } \\
\text { Tsuda, Hiroyuki; Nagoya City University, Nanotoxicology Project }\end{array}$ \\
\hline \multirow{2}{*}{ Keyword: } & \begin{tabular}{l} 
Lactoferrin, Crohn's Disease, Crohn's colitis \\
\hline
\end{tabular} \\
\hline
\end{tabular}

\section{SCHOLARONE"}

Manuscripts 


\section{Bovine lactoferrin and Crohn's Disease: A case study}

\section{David B. Alexander ${ }^{*}$, Masaaki Iigo ${ }^{1}$, Mohamed Abdelgied ${ }^{1,2,3}$, Keiji Ozeki ${ }^{4}$, Satoshi Tanida ${ }^{4}$, Takashi $\mathrm{Joh}^{4}$, Satoru Takahashi ${ }^{5}$, and Hiroyuki Tsuda ${ }^{{ }^{*}}$}

${ }^{1}$ Nanotoxicology Project, Nagoya City University, Nagoya, Japan.

${ }^{2}$ Department of Experimental Pathology and Tumor Biology, Nagoya City University Graduate School of Medical Sciences, Nagoya, Japan

${ }^{3}$ Department of Forensic Medicine and Toxicology, Faculty of Veterinary Medicine, Beni-Suef University, Beni-Suef, Egypt

${ }^{4}$ Department of Gastroenterology and Metabolism, Nagoya City University Graduate School of Medical Sciences, Nagoya, Japan.

${ }^{5}$ Department of Experimental Pathology and Tumor Biology, Nagoya City University Graduate School of Medical Sciences, Nagoya, Japan

*Correspondence:

David B. Alexander

Nanotoxicology Project, Nagoya City University, Nagoya, Japan.

Tel: +81-052-836-3496; Fax: +81-052-836-3497

E-mail: dalexand@phar.nagoya-cu.ac.jp

Hiroyuki Tsuda

Nanotoxicology Project, Nagoya City University, Nagoya, Japan.

Tel: +81-052-836-3496; Fax: +81-052-836-3497

E-mail: htsud@phar.nagoya-cu.ac.jp 


\begin{abstract}
A 22 year old male suffering from abdominal pain, repeated diarrhea, and weight loss visited the Digestive Disease Department of Nagoya City University Hospital on Dec. 19, 2011. He was hospitalized and diagnosed with Crohn's colitis. His Crohn's Disease Activity Index (CDAI) was 415. Treatment by granulocyte apheresis, mesalazine, and adalimumab was started. His CDAI was 314 on Dec 30 and 215 on Jan. 5. A colonoscopic examination on Jan. 19 showed almost complete remission in the transverse colon and marked remission in the rectum. Mesalazine therapy stopped on Feb 28, and the patient was instructed to self-inject $40 \mathrm{mg}$ adalimumab every other week. His CDAI was 50 on April 10 indicating clinical remission. His last selfinjection of adalimumab was April 24, 2012, and he started taking $1 \mathrm{~g}$ bovine lactoferrin (bLF) daily. His CDAI was 35 on Jan 08, 2013. He continued taking $1 \mathrm{~g}$ bLF daily without any other treatment for Crohn's disease. Laboratory blood tests on Sept 07,2015 , showed no sign of disease recurrence, and a colonoscopic examination on Oct 23, 2015, showed almost complete mucosal healing. This case indicates that ingestion of bLF to maintain Crohn's disease in a remissive state should be further explored.
\end{abstract}

Crohn's disease, Crohn's colitis, bovine lactoferrin 


\section{Introduction}

Lactoferrin (LF) is abundantly expressed in tissues and fluids where the body interacts with external microbes: Neutrophils exocytose LF containing granules at sites of infection; LF in seminal fluid helps to protect sperm from the microflora of the vagina; LF present in the mucosa of the upper respiratory tract and tear film helps to protect these surfaces from invading pathogens; and LF in milk helps to protect the developing gastrointestinal tract of the suckling infant (Alexander et al. 2012). An essential feature of LF associated with its protective function against microbes is that LF inhibits attachment and invasion of target cells by microbes without killing them and generating microbial antigens, allowing microbial removal without causing inflammation and consequent tissue damage (Alexander et al. 2012). Thus, in the tissues and fluids where it is found, LF is a crucial component of the barrier that all multicellular organisms must maintain against microbes.

Crohn's Disease is an impaired barrier disease of the intestine (Antoni et al. 2014; Wehkamp et al. 2008). A striking characteristic of Crohn's disease is decreased expression of defensins: There is a strong association between defective $\alpha$-defensin production by Paneth cells and ileal Crohn's Disease (Jager et al. 2013; Wehkamp et al. 2005; Wehkamp and Stange 2006), and colonic Crohn's Disease is associated with defective $\beta$-defensin production (Nuding et al. 2007; Wehkamp et al. 2005; Wehkamp and Stange 2006). A defective intestinal barrier allows adherence and invasion of the intestinal epithelium by luminal bacteria and consequent triggering of the host's immune response. In the absence of mucosal healing and restoration of the intestinal barrier, this will result in the chronic inflammation that is a hallmark of inflammatory bowel diseases.

While endogenous human LF is not part of the intestinal barrier (Alexander et 
al. 2012), ingested LF does appear to have activity in the colon. For example, in a placebo controlled clinical trial, participants with colorectal polyps ingesting $3 \mathrm{~g}$ bovine LF (bLF) daily for 1 year had enhanced expression of type 1 interferons in the colon, an altered population of immune cells in their colorectal polyps, and decreased colorectal polyp growth (Alexander et al. 2014; Iigo et al. 2014; Kozu et al. 2009). Since ingested bLF is digested in the stomach and intestine of the adult and neither the bLF protein nor its digested fragments reach the colon in significant amounts or bind to receptors that would affect type 1 interferon expression or immune cell function ((Alexander et al. 2014): Supplementary Text S2), the effects of ingested bLF in the adult colon are likely to be indirect.

\section{Materials and Methods}

The patient took 3 bovine lactoferrin containing tablets orally every morning with a glass of water. The tablets were ingested at least $30 \mathrm{~min}$ before the patient consumed anything else. The bovine lactoferrin containing tablets were purchased from Nutricology (Item \# 52080) (Alameda, CA. USA). Each tablet contained $350 \mathrm{mg}$ bovine lactoferrin. Other ingedients included hydroxypropyl methylcellulose, microcrystalline cellulose, 1-leucine. Nutricology did not respond to requests for additional information on the contents of the tablets.

\section{Results}

While residing in the USA, the patient (Patient A), a 22 year old male, had been suffering from abdominal pain, repeated diarrhea, and weight loss. In mid-December, he returned to Japan and on Dec. 19, 2011, he visited the Digestive Disease Department of the Nagoya City University Hospital. Physical examination showed 
edema, anemia, and ascites, and computed tomography revealed extensive thickening of the wall of the sigmoid colon and rectum suggestive of inflammatory bowel disease. He was hospitalized as an emergency patient due to his symptoms and malnutrition. On Dec. 20, a colonoscopy from the rectum through the transverse colon showed extensive erosive and ulcerative lesions and erythematous (color) and edematous (swelling) changes in the mucosa from the sigmoid colon through the transverse colon (Fig. 1). Biopsy revealed the presence of a noncaseating epithelioid granuloma (see Turner et al. 2014). Tests for infectious diseases that could mimic Crohn's disease symptoms, including Clostridium difficile, were negative, and he was diagnosed with Crohn's disease of the colon (Crohn's colitis). His Crohn's Disease Activity Index (CDAI) was 415.

After confirmation that Patient A was free from infections such as Hepatitis B virus, Hepatitis C virus, HIV, HTLV, and tuberculosis that could be exacerbated by immunosuppressive therapy, treatment by granulocyte apheresis (granulocyte removal therapy: see Yamamoto et al. 2006), the anti-inflammatory agent Pentasa (mesalazine, 3000 mg/day: see Karagozian and Burakoff 2007), and Humira (the TNF-alpha antibody adalimumab: see Colombel et al. 2007) was started. The initial injection of Humira was $160 \mathrm{mg}$ followed two weeks later by an injection of $80 \mathrm{mg}$. His CDAI was 314 on Dec 30 and 215 on Jan 5, 2012, when Patient A was discharged from the hospital. Pentasa therapy and maintenance doses of $40 \mathrm{mg}$ Humira were administered every other week at the out patient clinic. A second total colonoscopic examination performed on Jan. 19 showed mucosal healing from the transverse colon to the cecum and marked improvement of ulcerative lesions from the sigmoid colon to the transverse colon (Fig. 2).

Mesalazine therapy was stopped on Feb 28. Patient A was instructed to self- 
inject $40 \mathrm{mg}$ Humira every other week. His CDAI was 50 on April 10 indicating clinical remission. Thus, after a course of granulocyte apheresis, approximately 2 months of mesalazine administration $(3000 \mathrm{mg}$ /daily from $22 \mathrm{Dec} 2011$ to $28 \mathrm{Feb}$ 2012), and 9 injections of Humira (160 mg on 22 Dec 2011, 80 mg on 5 Jan 2012, 40 mg every other week thereafter) the disease was in remission.

Patient A's last self-injection of Humira was April 24, 2012 (a total of 10 injections). He left Japan and returned to the USA at the beginning of May. In the USA, due to the difficulty of obtaining medical insurance with a pre-existing condition and the high cost of medical anti-TNF-alpha antibodies such as adalimumab and infliximab, the patient was compelled to try to find an alternative. He started taking $1 \mathrm{~g}$ bovine lactoferrin (bLF) with a glass of water every morning at least 30 min before consuming anything else. He returned to Japan in 2013, and his CDAI was 35 on Jan 08, 2013. In Japan, the patient continued taking $1 \mathrm{~g}$ bLF daily, but did not restart medical anti-TNF-alpha antibody injections or any other Crohn's disease medication.

Laboratory blood tests on Sept 07, 2015, showed no sign of disease recurrence, and a colonoscopic examination on Oct 23,2015 , showed almost complete mucosal healing with only a few residual inflammatory polyps (Fig. 3). A fecal exam did not detect pathogenic bacteria, including Clostridium difficile (see Ananthakrishnan et al. 2010). Thus, Patient A while ingesting bLF has remained in clinical remission for more than $3^{1 /} / 2$ years, and at the time of this writing Patient $A$ has been symptom free for $4 \frac{1}{2}$ years.

\section{Discussion}


It is important to recognize that Patient A begin taking bLF tablets after his disease was diagnosed as being in remission following treatment with granulocyte apheresis, Pentasa, and Humira, as described above. Therefore, the case study described in this report does not indicate that lactoferrin can be used to treat active Crohn's disease. However, this case study does suggest that ingestion of lactoferrin may be able to promote a healthy intestinal mucosa and maintain Crohn's disease in a remissive state.

How significant is the $3 \frac{1}{2}$ to $4 \frac{1}{2}$ year remission status of Patient A? Crohn's disease is a chronic, recurrent, inflammatory disease of the gastrointestinal tract. Two literature surveys found that only approximately $10 \%$ of patients being treated for Crohn's disease experience prolonged clinical remission (prolonged was not defined in these reports) (Loftus et al. 2002; Peyrin-Biroulet et al. 2010). A long-term followup of 185 Crohn's disease patients reported that after 5 and 10 years $93 \%$ and $99 \%$ of the patients had experienced at least one relapse (Binder et al. 1985). A more recent 10-year follow-up study of a cohort of 237 Crohn's disease patients reported cumulative relapse rates of $53 \%, 85 \%$, and $90 \%$ at 1,5 , and 10 years (Solberg et al. 2007). A 35-year follow-up of 507 patients treated for colorectal Crohn's disease reported that of 407 patients who attained clinical remission without surgery and in whom further clinical course could be determined, only 29 had a non-relapsing course and all 12 of the non-treated patients who attained remission subsequently had a relapse; median follow-up time was 13.4 years, 0.5 - 319 months (Lapidus et al. 1998). The cumulative rates of relapse in these patients at $1,2,5$, and 10 years after diagnosis were $20 \%, 40 \%, 67 \%$, and $76 \%$, respecitvely. While Patient A can not be directly compared with the patients followed in the studies noted here, since they were under clinical care, Patient A does compare favorably with these patients. 
Table 1 lists several trials in which patients with colitis (Crohn's disease of the colon) and/or ileocolitis (Crohn's disease of the ileum and the colon) attained remission and were subsequently followed for maintenance of remission. The data shown is from patients who stopped taking medications after their disease was in remission and were followed-up (studies 19, 25-28) or entered the no treatment arm (studies 7, 8, 11, 13) or placebo arm (studies 1-6, 9, 10, 12, 14-18, 20-24) of clinical trials. The placebo arm of these studies did not receive concomitant medication. Studies that contained (1) only patients with Crohn's disease limited to the ileal or ileo-caecal region and/or ascending colon, (2) studies that contained only patients with surgically induced remission, and (3) studies in which medication was withdrawn before the patient had established remission are not listed in Table 1: The first two types of studies are not directly relevant to Patient A and the last type of study has high relapse rates, $70 \%$ or more within the first year (Colombel et al. 2007; Hanauer et al. 2002; Rutgeerts et al. 2004; Rutgeerts et al. 2012; Schreiber et al. 2007). Relapse rates vary markedly in the studies listed in Table 1, with most of these studies reporting relpse rates between $30 \%$ and $70 \%$ during the first year after medication withdrawal. The reason for this wide range of relapse rates between studies is unknown. There does not appear to be a relationship between disease location and short-term relapse rate; only study 23 reports a different relapse rate between patients with Crohn's colitis, ileocolitis, and ileitis. Study 28 found that younger age at diagnosis and male gender were associated with a higher risk of relapse, but study 12 did not find an association of relapse rate with any of the following parameters: age, gender, disease duration, previous surgery, previous steroid therapy, entrance CDAI, disease localization, extraintestinal manifestations, perianal lesions during acute disease, response to acute phase treatment, blood 
sedimentation rate, or $\mathrm{C}$ reactive protein at time of randomization. Studies 19 and 26 also report that there were no predictive factors for relapse/remission after medication withdrawal. One factor that does appear to be associated with relapse is the time in remission before withdrawal of medication: see study 21 . Studies 14 and 28 also found a decrease in the risk of relapse in patients with prolonged prestudy remission, and Holtmann, et al. (2006) report that after 3-4 years in complete remission while on azathioprine therapy, withdrawal of medication did not result in clinical deterioration for the remainder of the study. Finally, studies 20 and 27 report low relapse rates in the first 1 to 1.5 years, and both these studies followed patients with prolonged prestudy remission times. Time in remission, in turn, may be related to mucosal healing. However, while some studies have found a relationship between mucosal healing and relapse rates (Baert et al. 2010; Froslie et al. 2007; Papamichael et al. 2015; Schnitzler et al. 2009b), other studies haven't (Farkas et al. 2014; Landi et al. 1992; Lemann et al. 2005; Rutgeerts et al. 2006). Another possibility is that time in remission reflects disease severity, i.e., patients with extended prestudy remission times have lower disease severity, and hence, are less likely to relapse after medication withdrawal. This suggests that one reason for the prolonged remission experienced by Patient A may be low disease activity. However, at the time of diagnosis of Crohn's colitis in 2011, pathological examination revealed the presence of a noncaseating epitheliod granuloma, and this lesion is associated with increased clinical severity of Crohn's disease (Turner et al. 2014), indicating that the patient's prolonged remission is not due to initial low disease activity.

Studies 4, 21, 22, and 26-28 in Table 1 illustrate the well-known increase of cumulative relapse rates over time in Crohn's disease patients. Crohn's disease has both environmental and genetic components (Ostaff et al. 2013); consequently, it can 
be controlled but not cured, which accounts for the steady increase in cumulative relapses over time. At $3 \frac{1}{2}$ to $4 \frac{1}{2}$ years in remission, Patient A's disease is well controlled.

Another point about the studies listed in Table 1 is that none of them induced remission using medical anti-TNF-alpha antibodies. This is because the placebo arm of trials testing anti-TNF-alpha therapy either started before the patients were confirmed to be in remission (Colombel et al. 2007; Hanauer et al. 2002; Rutgeerts et al. 2004; Rutgeerts et al. 2012; Schreiber et al. 2007) or they allowed use of concomitant medication. As noted above, the placebo arm of the first type of trial had high relapse rates, $70 \%$ or more within the first years. Table 2 lists several of the second type of study: Patients were treated with anti-TNF-alpha antibodies (infliximab or adalimumab: generally referred to as biological therapy in these studies), and concomitant with biological therapy steroid and/or immunosuppressive therapy was generally employed during initial treatment and was often continued after withdrawal of biological therapy. Two studies stand out in Table 2: Study 1, with a very high rate of relapse, and study 9 , with a very low rate of relapse. There are no obvious differences between the 22 patients in remission in study 1 and the patients in remission in studies 2-8, suggesting that the high number of relapses within 1 year in this study was due to chance. On the other hand, the extraordinary low rate of relapse in study 9 is possibly due to patient selection. While all of the patients in Table 2 responded to biological therapy and were in clinical remission or clinical remission + mucosal remission at the start of the follow-up period, only patients with a follow-up period of 2 years or more were included in study 9.

Because the outcome of patients who did not receive concomitant therapy after biological therapy withdrawal was not specifically recorded in the studies listed in 
Table 2, Patient A can not be directly compared with these patients; however, his time in remission does not contradict the possibility that ingestion of $1 \mathrm{~g}$ bLF daily is effective in maintaining remission after biological therapy withdrawal. Importantly, study 9 along with study 8 demonstrate that there is a subgroup of patients who will remain in prolonged remission after biological therapy is withdrawn. Therefore, it is possible that Patient A belongs to this subgroup. However, while this subgroup appears to have a significant number of patients, the percentage of Crohn's disease patients belonging to this subgroup is small, suggesting that some other factor may be responsible, at least in part, for Patient A's prolonged remission. One plausible factor is ingestion of bLF. However, it is also possible that an environmental trigger for his disease is more prevalent in the USA, where he developed the disease, than in Japan, where his disease remains in remission.

Is it credible that ingestion of bLF could affect Crohn's disease of the colon? As noted in the introduction, ingestion of bLF does appear to have an effect in the colon. We previously suggested one possible means by which ingested bLF could affect the colon (Alexander et al. 2014: Supplementary Text S2): Briefly, gastric digestion of bLF results in the generation of antimicrobial peptides (Furlund et al. 2013; Kuwata et al. 2001; Kuwata et al. 1998a; Kuwata et al. 1998b) that have the potential to kill a small fraction of intestinal microbes and produce microbial antigens such as lipopolysaccharide, lipoproteins, flagellin, and unmethylated CpG-containing DNA that are able to interact with pattern recognition receptors (PRRs) expressed by intestinal epithelial and immune cells (Abreu et al. 2005; Artis 2008; Rakoff-Nahoum et al. 2004). Interaction between microbial antigens and intestinal epithelial PRRs increases expression of IgA (Wells et al. 2011) and antimicrobial peptides (Froy 2005; Vora et al. 2004), thereby enhancing the barrier function of the overlying mucosal 
layer of the intestinal epithelium (see Johansson et al. 2011), protecting the epithelium from the intestinal microbiota and helping to maintain remission in Crohn's disease patients. This proposal assumes (1) that microbial killing by bLF derived peptides results in an elevation of microbial antigens that reach the surface of the intestinal epithelium and (2) that the consequent increased production of antimicrobial factors is able to offset the deficiencies that can lead to development of Crohn's disease. Another proposal is that antimicrobial peptides can influence the composition of the intestinal microbiota and help to control Crohn's disease (Gunther et al. 2016). In support of this proposal, (1) a subset of Crohn's disease samples contain abnormal gastrointentinal microbiotas (Frank et al. 2007); (2) it has been shown that in mice, transfer of dysbiotic intestinal microbiota to genetically susceptible germ-free mice resulted in Crohn's disease-like inflammation (Schaubeck et al. 2016); and (3) that oral administration of a synthetic antimicrobial peptide to mice induced significant changes in the composition of the intestinal microbiota (Dupont et al. 2015).

This case study is the only physician-certified report of the status of Crohn's disease in a patient ingesting bLF. Is there any other evidence that ingested bLF is able to affect the status of Crohn's disease? There are a few studies using animal models of Crohn's disease that report on the effect of ingested LF. However, these animal models are of active Crohn's disease, and the results of the studies are mixed. For example, Togawa et al. (2002), Haversen et al. (2003), and Li et al. (2013) report suppression of active disease in trinitrobenzenesulfonic acid (TNBS)-induced colitis in rats and dextran sulphate (DSS)-induced colitis in mice, but Bodammer et al. (2013) report that administration of bLF did not affect the course of DSS-induced colitis in mice. Importantly, ingested lactoferrin (LF) is unlikely to directly affect the mucosa affected by active Crohn's colitis as (1) neither ingested LF nor peptides 
derived from digested LF reach the ceacum or colon in rats (Kuwata et al. 2001) or the colon in humans (Troost et al. 2002), and (2) abundant neutrophil-derived lactoferrin is present in the colons of patients with active Crohn's colitis (Walker et al. 2007). Therefore, the effects of ingested LF on Crohn's colitis is most likely indirect; for example, as suggested above, via interaction of peptides derived from gastric digestion of bLF with the intestinal microbiota. Notably, in the study by Haversen et al. (2003), administration of two peptides derived from the bactericidal region of hLF (hLF_16-40 and hLF_18-40) had similar results to hLF administration and Li et al. (2013) suggest (data not shown) that the effects of apo-bLF in their study were dependent on restoration of homeostasis of the intestinal bacteria. Finally, an indirect action of LF on chemically-induced colitis could also account for the different results obtained by the groups cited above: the results could depend on the digestion of the administered lactoferrin (Bodammer administered bLF by gavage to mice while Haverson et al. applied hLF to the back of the tongue of the mice) and the severity of the disease (Bodammer et al. used 5\% DSS in the drinking water of mice for 7 days while Li et al. used 2.5\% DSS in the drinking water of mice for 7 days and Togawa used TNBS to induce colitis in rats). Overall, there is some support from animal studies that ingestion of bLF could affect the status of Crohn's colitis.

Is ingestion by Crohn's disease patients in remission safe? One critically important factor is a patient's response to re-introduction of therapy. Studies 1, 4, 5, and 8 in Table 2 indicate that the response of a relapsing patient to restarting antiTNF $\alpha$ antibody therapy is excellent. In addition, in study 27 in Table 1, 23 of 24 relapsing patients retreated with azathioprine entered remission. Another factor is the effect of prolonged exposure of the intestine to the antimicrobial peptides generated by gastric digestion of bLF. To date, no adverse effects have been reported in humans 
ingesting lactoferrin. In trials with patients with chronic hepatitis $\mathrm{C}, 15$ patients were given $3.6 \mathrm{~g}$ bLF daily for 6 months (Iwasa et al. 2002), 15 patients were given $7.2 \mathrm{~g}$ bLF daily for 8 weeks (Okada et al. 2002), and 97 patients were given $1.8 \mathrm{~g}$ bLF daily for 12 weeks (Ueno et al. 2006). In a clinical trial to determine whether ingestion of bLF had an effect on colorectal polyp growth, 34 patients ingested $3.0 \mathrm{~g}$ bLF daily for one year (Kozu et al. 2009). Four long term cancer survivors with metastatic renal cell carcinoma received recombinant human lactoferrin at a dose of $9 \mathrm{~g}$ per day given in cycles of 2 weeks on/2 weeks off for 30 months or longer (Lewis and Hayes 2011). Finally, the European Food Safety Authority (EFSA) Panel on Dietetic Products, Nutrition and Allergies (NDA) has concluded that intake of bLF up to $3.4 \mathrm{~g}$ per day by an adult is safe (EFSA 2012).

Concluding remarks: Crohn's colitis in Patient A has been in clinical remission for at least $3 \frac{1}{2}$ years and in symptomatic remission for $4 \frac{1}{2}$ years. It is plausible that ingestion of $1 \mathrm{~g}$ bLF daily has helped maintain this remissive state; although, environmental factors can not be ruled out. It has been suggested that stimulation of the protective innate immune system of the intestine could help protect against Crohn's disease (Gersemann et al. 2008). Ingestion of bLF has the potential to stimulate the intestinal epithelium to produce antimicrobial agents, thus protecting the epithelium against the intestinal microbiota. As discussed above, it has also been suggested that the microbiota associated with active Crohn's disease can be abnormal and that ingestion of antimicrobial peptides may be able to induce changes in the composition of the intestinal microbiota and affect the course of the disease. Ingestion of bLF is safe and ingestion of bLF to maintain Crohn's disease in a remissive state should be further explored. 


\section{References}

Abreu, M.T., Fukata, M., and Arditi, M. 2005. TLR signaling in the gut in health and disease. J Immunol 174(8): 4453-4460.

Alexander, D.B., Iigo, M., Hamano, H., Kozu, T., Saito, Y., Saito, D., Kakizoe, T., Xu, J., Yamauchi, K., Takase, M., Suzui, M., and Tsuda, H. 2014. An ancillary study of participants in a randomized, placebo-controlled trial suggests that ingestion of bovine lactoferrin promotes expression of interferon alpha in the human colon. Journal of Functional Foods 10: 305-317. doi: 10.1016/j.jff.2014.06.028.

Alexander, D.B., Iigo, M., Yamauchi, K., Suzui, M., and Tsuda, H. 2012. Lactoferrin: an alternative view of its role in human biological fluids. Biochem Cell Biol 90(3): 279-306. doi: 10.1139/o2012-013.

Ampuero, J., Rojas-Feria, M., Castro-Fernandez, M., Millan-Lorenzo, M., GuerreroJimenez, P., and Romero-Gomez, M. 2016. Remission maintained by monotherapy after biological + immunosuppressive combination for Crohn's disease in clinical practice. J Gastroenterol Hepatol 31(1): 112-118. doi: 10.1111/jgh.13039.

Ananthakrishnan, A.N., Issa, M., and Binion, D.G. 2010. Clostridium difficile and inflammatory bowel disease. Med Clin North Am 94(1): 135-153. doi: 10.1016/j.mcna.2009.08.013.

Antoni, L., Nuding, S., Wehkamp, J., and Stange, E.F. 2014. Intestinal barrier in inflammatory bowel disease. World J Gastroenterol 20(5): 1165-1179. doi: 10.3748/wjg.v20.i5.1165.

Arber, N., Odes, H.S., Fireman, Z., Lavie, A., Broide, E., Bujanover, Y., Becker, S., Pomerantz, I., Moshkowitz, M., Patz, J., and et al. 1995. A controlled double blind multicenter study of the effectiveness of 5-aminosalicylic acid in patients with Crohn's disease in remission. J Clin Gastroenterol 20(3): 203-206.

Artis, D. 2008. Epithelial-cell recognition of commensal bacteria and maintenance of immune homeostasis in the gut. Nat Rev Immunol 8(6): 411-420. doi: $10.1038 /$ nri2316.

Baert, F., Moortgat, L., Van Assche, G., Caenepeel, P., Vergauwe, P., De Vos, M., Stokkers, P., Hommes, D., Rutgeerts, P., Vermeire, S., D'Haens, G., Belgian Inflammatory Bowel Disease Research, G., and North-Holland Gut, C. 2010. Mucosal healing predicts sustained clinical remission in patients with early-stage Crohn's disease. Gastroenterology 138(2): 463-468; quiz e410-461. doi: $10.1053 /$ j.gastro.2009.09.056.

Binder, V., Hendriksen, C., and Kreiner, S. 1985. Prognosis in Crohn's disease--based on results from a regional patient group from the county of Copenhagen. Gut 26(2): 146-150.

Bodammer, P., Zirzow, E., Klammt, S., Maletzki, C., and Kerkhoff, C. 2013. Alteration of DSS-mediated immune cell redistribution in murine colitis by oral colostral immunoglobulin. BMC Immunol 14: 10. doi: 10.1186/1471-2172-14-10. 
Bouhnik, Y., Lemann, M., Mary, J.Y., Scemama, G., Tai, R., Matuchansky, C., Modigliani, R., and Rambaud, J.C. 1996. Long-term follow-up of patients with Crohn's disease treated with azathioprine or 6-mercaptopurine. Lancet 347(8996): 215-219.

Bresci, G., Petrucci, A., and Banti, S. 1991. 5-aminosalicylic acid in the prevention of relapses of Crohn's disease in remission: a long-term study. Int J Clin Pharmacol Res 11(4): 200-202.

Brignola, C., Campieri, M., Farruggia, P., Tragnone, A., Pasquali, S., Iannone, P., Lanfranchi, G.A., and Barbara, L. 1988. The possible utility of steroids in the prevention of relapses of Crohn's disease in remission. A preliminary study. J Clin Gastroenterol 10(6): 631-634.

Brignola, C., Iannone, P., Pasquali, S., Campieri, M., Gionchetti, P., Belluzzi, A., Basso, O., Miglioli, M., and Barbara, L. 1992. Placebo-controlled trial of oral 5-ASA in relapse prevention of Crohn's disease. Dig Dis Sci 37(1): 29-32.

Candy, S., Wright, J., Gerber, M., Adams, G., Gerig, M., and Goodman, R. 1995. A controlled double blind study of azathioprine in the management of Crohn's disease. Gut 37(5): 674-678.

Colombel, J.F., Sandborn, W.J., Rutgeerts, P., Enns, R., Hanauer, S.B., Panaccione, R., Schreiber, S., Byczkowski, D., Li, J., Kent, J.D., and Pollack, P.F. 2007. Adalimumab for maintenance of clinical response and remission in patients with Crohn's disease: the CHARM trial. Gastroenterology 132(1): 52-65. doi: 10.1053/j.gastro.2006.11.041.

de Franchis, R., Omodei, P., Ranzi, T., Brignola, C., Rocca, R., Prada, A., Pera, A., Vecchi, M., Del Piano, M., Ferrara, A., Belloli, C., Piodi, L., Framarin, L., Astegiano, M., Riccioli, F.A., and Meucci, G. 1997. Controlled trial of oral 5-aminosalicylic acid for the prevention of early relapse in Crohn's disease. Aliment Pharmacol Ther 11(5): 845-852.

Dupont, A., Kaconis, Y., Yang, I., Albers, T., Woltemate, S., Heinbockel, L., Andersson, M., Suerbaum, S., Brandenburg, K., and Hornef, M.W. 2015. Intestinal mucus affinity and biological activity of an orally administered antibacterial and antiinflammatory peptide. Gut 64(2): 222-232. doi: 10.1136/gutjnl-2014-307150.

EFSA. 2012. Scientific Opinion on bovine lactoferrin. EFSA Panel on Dietetic Products, Nutrition and Allergies (NDA). . EFSA Journal 10(5). doi: 10.2903/j.efsa.2012.2701.

Farkas, K., Lakatos, P.L., Szucs, M., Pallagi-Kunstar, E., Balint, A., Nagy, F., Szepes, Z., Vass, N., Kiss, L.S., Wittmann, T., and Molnar, T. 2014. Frequency and prognostic role of mucosal healing in patients with Crohn's disease and ulcerative colitis after one-year of biological therapy. World J Gastroenterol 20(11): 2995-3001. doi: 10.3748/wjg.v20.i11.2995.

Feagan, B.G., Fedorak, R.N., Irvine, E.J., Wild, G., Sutherland, L., Steinhart, A.H., Greenberg, G.R., Koval, J., Wong, C.J., Hopkins, M., Hanauer, S.B., and McDonald, J.W. 2000. A comparison of methotrexate with placebo for the maintenance of remission in Crohn's disease. North American Crohn's Study Group Investigators. N 
Engl J Med 342(22): 1627-1632. doi: 10.1056/NEJM200006013422202.

Frank, D.N., St Amand, A.L., Feldman, R.A., Boedeker, E.C., Harpaz, N., and Pace, N.R. 2007. Molecular-phylogenetic characterization of microbial community imbalances in human inflammatory bowel diseases. Proc Natl Acad Sci U S A 104(34): 13780-13785. doi: 10.1073/pnas.0706625104.

Fraser, A.G., Orchard, T.R., and Jewell, D.P. 2002. The efficacy of azathioprine for the treatment of inflammatory bowel disease: a 30 year review. Gut 50(4): 485-489.

Froslie, K.F., Jahnsen, J., Moum, B.A., Vatn, M.H., and Group, I. 2007. Mucosal healing in inflammatory bowel disease: results from a Norwegian population-based cohort. Gastroenterology 133(2): 412-422. doi: 10.1053/j.gastro.2007.05.051.

Froy, O. 2005. Regulation of mammalian defensin expression by Toll-like receptordependent and independent signalling pathways. Cell Microbiol 7(10): 1387-1397. doi: $10.1111 / \mathrm{j} .1462-5822.2005 .00590 . x$.

Furlund, C.B., Ulleberg, E.K., Devold, T.G., Flengsrud, R., Jacobsen, M., Sekse, C., Holm, H., and Vegarud, G.E. 2013. Identification of lactoferrin peptides generated by digestion with human gastrointestinal enzymes. J Dairy Sci 96(1): 75-88. doi: 10.3168/jds.2012-5946.

Gendre, J.P., Mary, J.Y., Florent, C., Modigliani, R., Colombel, J.F., Soule, J.C., Galmiche, J.P., Lerebours, E., Descos, L., Viteau, J.M., and et al. 1993. Oral mesalamine (Pentasa) as maintenance treatment in Crohn's disease: a multicenter placebo-controlled study. The Groupe d'Etudes Therapeutiques des Affections Inflammatoires Digestives (GETAID). Gastroenterology 104(2): 435-439.

Gersemann, M., Wehkamp, J., Fellermann, K., and Stange, E.F. 2008. Crohn's disease--defect in innate defence. World J Gastroenterol 14(36): 5499-5503.

Gross, V., Andus, T., Ecker, K.W., Raedler, A., Loeschke, K., Plauth, M., Rasenack, J., Weber, A., Gierend, M., Ewe, K., and Scholmerich, J. 1998. Low dose oral pH modified release budesonide for maintenance of steroid induced remission in Crohn's disease. The Budesonide Study Group. Gut 42(4): 493-496.

Gunther, C., Josenhans, C., and Wehkamp, J. 2016. Crosstalk between microbiota, pathogens and the innate immune responses. Int $\mathrm{J}$ Med Microbiol. doi: 10.1016/j.ijmm.2016.03.003.

Hanauer, S.B., Feagan, B.G., Lichtenstein, G.R., Mayer, L.F., Schreiber, S., Colombel, J.F., Rachmilewitz, D., Wolf, D.C., Olson, A., Bao, W., Rutgeerts, P., and Group, A.I.S. 2002. Maintenance infliximab for Crohn's disease: the ACCENT I randomised trial. Lancet 359(9317): 1541-1549. doi: 10.1016/S0140-6736(02)085124.

Haversen, L.A., Baltzer, L., Dolphin, G., Hanson, L.A., and Mattsby-Baltzer, I. 2003. Anti-inflammatory activities of human lactoferrin in acute dextran sulphate-induced colitis in mice. Scand J Immunol 57(1): 2-10.

Holtmann, M.H., Krummenauer, F., Claas, C., Kremeyer, K., Lorenz, D., Rainer, O., Vogel, I., Bocker, U., Bohm, S., Buning, C., Duchmann, R., Gerken, G., Herfarth, H., 
Lugering, N., Kruis, W., Reinshagen, M., Schmidt, J., Stallmach, A., Stein, J., Sturm, A., Galle, P.R., Hommes, D.W., D'Haens, G., Rutgeerts, P., and Neurath, M.F. 2006. Long-term effectiveness of azathioprine in IBD beyond 4 years: a European multicenter study in 1176 patients. Dig Dis Sci 51(9): 1516-1524. doi: 10.1007/s10620-005-9037-5.

Iigo, M., Alexander, D.B., Xu, J., Futakuchi, M., Suzui, M., Kozu, T., Akasu, T., Saito, D., Kakizoe, T., Yamauchi, K., Abe, F., Takase, M., Sekine, K., and Tsuda, H. 2014. Inhibition of intestinal polyp growth by oral ingestion of bovine lactoferrin and immune cells in the large intestine. Biometals 27(5): 1017-1029. doi: 10.1007/s10534-014-9747-2.

IMSG. 1990. Coated oral 5-aminosalicylic acid versus placebo in maintaining remission of inactive Crohn's disease. International Mesalazine Study Group. Aliment Pharmacol Ther 4(1): 55-64.

Iwasa, M., Kaito, M., Ikoma, J., Takeo, M., Imoto, I., Adachi, Y., Yamauchi, K., Koizumi, R., and Teraguchi, S. 2002. Lactoferrin inhibits hepatitis C virus viremia in chronic hepatitis $\mathrm{C}$ patients with high viral loads and HCV genotype 1b. Am J Gastroenterol 97(3): 766-767. doi: 10.1111/j.1572-0241.2002.05573.x.

Jager, S., Stange, E.F., and Wehkamp, J. 2013. Inflammatory bowel disease: an impaired barrier disease. Langenbecks Arch Surg 398(1): 1-12. doi: 10.1007/s00423012-1030-9.

Johansson, M.E., Larsson, J.M., and Hansson, G.C. 2011. The two mucus layers of colon are organized by the MUC2 mucin, whereas the outer layer is a legislator of host-microbial interactions. Proc Natl Acad Sci U S A 108 Suppl 1: 4659-4665. doi: 10.1073/pnas. 1006451107.

Karagozian, R., and Burakoff, R. 2007. The role of mesalamine in the treatment of ulcerative colitis. Ther Clin Risk Manag 3(5): 893-903.

Kozu, T., Iinuma, G., Ohashi, Y., Saito, Y., Akasu, T., Saito, D., Alexander, D.B., Iigo, M., Kakizoe, T., and Tsuda, H. 2009. Effect of orally administered bovine lactoferrin on the growth of adenomatous colorectal polyps in a randomized, placebo-controlled clinical trial. Cancer Prev Res (Phila) 2(11): 975-983. doi: 10.1158/1940-6207.CAPR08-0208.

Kuwata, H., Yamauchi, K., Teraguchi, S., Ushida, Y., Shimokawa, Y., Toida, T., and Hayasawa, H. 2001. Functional fragments of ingested lactoferrin are resistant to proteolytic degradation in the gastrointestinal tract of adult rats. J Nutr 131(8): 21212127.

Kuwata, H., Yip, T.T., Tomita, M., and Hutchens, T.W. 1998a. Direct evidence of the generation in human stomach of an antimicrobial peptide domain (lactoferricin) from ingested lactoferrin. Biochim Biophys Acta 1429(1): 129-141.

Kuwata, H., Yip, T.T., Yip, C.L., Tomita, M., and Hutchens, T.W. 1998b. Direct detection and quantitative determination of bovine lactoferricin and lactoferrin fragments in human gastric contents by affinity mass spectrometry. Adv Exp Med Biol 443: 23-32. 
Landi, B., Anh, T.N., Cortot, A., Soule, J.C., Rene, E., Gendre, J.P., Bories, P., See, A., Metman, E.H., Florent, C., and et al. 1992. Endoscopic monitoring of Crohn's disease treatment: a prospective, randomized clinical trial. The Groupe d'Etudes Therapeutiques des Affections Inflammatoires Digestives. Gastroenterology 102(5): 1647-1653.

Lapidus, A., Bernell, O., Hellers, G., and Lofberg, R. 1998. Clinical course of colorectal Crohn's disease: a 35-year follow-up study of 507 patients. Gastroenterology 114(6): 1151-1160.

Lemann, M., Mary, J.Y., Colombel, J.F., Duclos, B., Soule, J.C., Lerebours, E., Modigliani, R., Bouhnik, Y., and Groupe D'Etude Therapeutique des Affections Inflammatoires du Tube, D. 2005. A randomized, double-blind, controlled withdrawal trial in Crohn's disease patients in long-term remission on azathioprine. Gastroenterology 128(7): 1812-1818.

Lennard-Jones, J.E. 1977. Sulphasalazine in asymptomatic Crohn's disease. A multicentre trial. Gut 18(1): 69-72.

Lewis, M.A., and Hayes, T.G. 2011. Talactoferrin immunotherapy in metastatic renal cell carcinoma: a case series of four long-term survivors. J Clin Med Res 3(1): 47-51. doi: $10.4021 /$ jocmr499w.

Li, L., Ren, F., Yun, Z., An, Y., Wang, C., and Yan, X. 2013. Determination of the effects of lactoferrin in a preclinical mouse model of experimental colitis. Mol Med Rep 8(4): 1125-1129. doi: 10.3892/mmr.2013.1632.

Loftus, E.V., Jr., Schoenfeld, P., and Sandborn, W.J. 2002. The epidemiology and natural history of Crohn's disease in population-based patient cohorts from North America: a systematic review. Aliment Pharmacol Ther 16(1): 51-60.

Louis, E., Mary, J.Y., Vernier-Massouille, G., Grimaud, J.C., Bouhnik, Y., Laharie, D., Dupas, J.L., Pillant, H., Picon, L., Veyrac, M., Flamant, M., Savoye, G., Jian, R., Devos, M., Porcher, R., Paintaud, G., Piver, E., Colombel, J.F., Lemann, M., and Groupe D'etudes Therapeutiques Des Affections Inflammatoires, D. 2012. Maintenance of remission among patients with Crohn's disease on antimetabolite therapy after infliximab therapy is stopped. Gastroenterology 142(1): 63-70 e65; quiz e31. doi: 10.1053/j.gastro.2011.09.034.

Mahmud, N., Kamm, M.A., Dupas, J.L., Jewell, D.P., O'Morain, C.A., Weir, D.G., and Kelleher, D. 2001. Olsalazine is not superior to placebo in maintaining remission of inactive Crohn's colitis and ileocolitis: a double blind, parallel, randomised, multicentre study. Gut 49(4): 552-556.

Malchow, H., Ewe, K., Brandes, J.W., Goebell, H., Ehms, H., Sommer, H., and Jesdinsky, H. 1984. European Cooperative Crohn's Disease Study (ECCDS): results of drug treatment. Gastroenterology 86(2): 249-266.

Modigliani, R., Colombel, J.F., Dupas, J.L., Dapoigny, M., Costil, V., Veyrac, M., Duclos, B., Soule, J.C., Gendre, J.P., Galmiche, J.P., Danne, O., Cadiot, G., Lamouliatte, H., Belaiche, J., and Mary, J.Y. 1996. Mesalamine in Crohn's disease with steroid-induced remission: effect on steroid withdrawal and remission maintenance, Groupe d'Etudes Therapeutiques des Affections Inflammatoires 
Digestives. Gastroenterology 110(3): 688-693.

Molander, P., Farkkila, M., Salminen, K., Kemppainen, H., Blomster, T., Koskela, R., Jussila, A., Rautiainen, H., Nissinen, M., Haapamaki, J., Arkkila, P., Nieminen, U., Kuisma, J., Punkkinen, J., Kolho, K.L., Mustonen, H., and Sipponen, T. 2014. Outcome after discontinuation of TNFalpha-blocking therapy in patients with inflammatory bowel disease in deep remission. Inflamm Bowel Dis 20(6): 1021-1028. doi: 10.1097/MIB.0000000000000052.

Molnar, T., Lakatos, P.L., Farkas, K., Nagy, F., Szepes, Z., Miheller, P., Horvath, G., Papp, M., Palatka, K., Nyari, T., Balint, A., Lorinczy, K., and Wittmann, T. 2013. Predictors of relapse in patients with Crohn's disease in remission after 1 year of biological therapy. Aliment Pharmacol Ther 37(2): 225-233. doi: 10.1111/apt. 12160.

Nuding, S., Fellermann, K., Wehkamp, J., and Stange, E.F. 2007. Reduced mucosal antimicrobial activity in Crohn's disease of the colon. Gut 56(9): 1240-1247. doi: 10.1136/gut.2006.118646.

Nyman, M., Hansson, I., and Eriksson, S. 1985. Long-term immunosuppressive treatment in Crohn's disease. Scand J Gastroenterol 20(10): 1197-1203.

Okada, S., Tanaka, K., Sato, T., Ueno, H., Saito, S., Okusaka, T., Sato, K., Yamamoto, S., and Kakizoe, T. 2002. Dose-response trial of lactoferrin in patients with chronic hepatitis C. Jpn J Cancer Res 93(9): 1063-1069.

Ostaff, M.J., Stange, E.F., and Wehkamp, J. 2013. Antimicrobial peptides and gut microbiota in homeostasis and pathology. EMBO Mol Med 5(10): 1465-1483. doi: 10.1002/emmm.201201773.

Papamichael, K., Vande Casteele, N., Gils, A., Tops, S., Hauenstein, S., Singh, S., Princen, F., Van Assche, G., Rutgeerts, P., Vermeire, S., and Ferrante, M. 2015. Longterm outcome of patients with Crohn's disease who discontinued infliximab therapy upon clinical remission. Clin Gastroenterol Hepatol 13(6): 1103-1110. doi: 10.1016/j.cgh.2014.11.026.

Peyrin-Biroulet, L., Loftus, E.V., Jr., Colombel, J.F., and Sandborn, W.J. 2010. The natural history of adult Crohn's disease in population-based cohorts. Am J Gastroenterol 105(2): 289-297. doi: 10.1038/ajg.2009.579.

Prantera, C., Pallone, F., Brunetti, G., Cottone, M., and Miglioli, M. 1992. Oral 5aminosalicylic acid (Asacol) in the maintenance treatment of Crohn's disease. The Italian IBD Study Group. Gastroenterology 103(2): 363-368.

Rakoff-Nahoum, S., Paglino, J., Eslami-Varzaneh, F., Edberg, S., and Medzhitov, R. 2004. Recognition of commensal microflora by toll-like receptors is required for intestinal homeostasis. Cell 118(2): 229-241. doi: 10.1016/j.cell.2004.07.002.

Rutgeerts, P., Diamond, R.H., Bala, M., Olson, A., Lichtenstein, G.R., Bao, W., Patel, K., Wolf, D.C., Safdi, M., Colombel, J.F., Lashner, B., and Hanauer, S.B. 2006. Scheduled maintenance treatment with infliximab is superior to episodic treatment for the healing of mucosal ulceration associated with Crohn's disease. Gastrointest Endosc 63(3): 433-442; quiz 464. doi: 10.1016/j.gie.2005.08.011. 
Rutgeerts, P., Feagan, B.G., Lichtenstein, G.R., Mayer, L.F., Schreiber, S., Colombel, J.F., Rachmilewitz, D., Wolf, D.C., Olson, A., Bao, W., and Hanauer, S.B. 2004. Comparison of scheduled and episodic treatment strategies of infliximab in Crohn's disease. Gastroenterology 126(2): 402-413.

Rutgeerts, P., Van Assche, G., Sandborn, W.J., Wolf, D.C., Geboes, K., Colombel, J.F., Reinisch, W., Investigators, E., Kumar, A., Lazar, A., Camez, A., Lomax, K.G., Pollack, P.F., and D'Haens, G. 2012. Adalimumab induces and maintains mucosal healing in patients with Crohn's disease: data from the EXTEND trial. Gastroenterology 142(5): 1102-1111 e1102. doi: 10.1053/j.gastro.2012.01.035.

Schaubeck, M., Clavel, T., Calasan, J., Lagkouvardos, I., Haange, S.B., Jehmlich, N., Basic, M., Dupont, A., Hornef, M., von Bergen, M., Bleich, A., and Haller, D. 2016. Dysbiotic gut microbiota causes transmissible Crohn's disease-like ileitis independent of failure in antimicrobial defence. Gut 65(2): 225-237. doi: 10.1136/gutjnl-2015309333.

Schnitzler, F., Fidder, H., Ferrante, M., Noman, M., Arijs, I., Van Assche, G., Hoffman, I., Van Steen, K., Vermeire, S., and Rutgeerts, P. 2009a. Long-term outcome of treatment with infliximab in 614 patients with Crohn's disease: results from a single-centre cohort. Gut 58(4): 492-500. doi: 10.1136/gut.2008.155812.

Schnitzler, F., Fidder, H., Ferrante, M., Noman, M., Arijs, I., Van Assche, G., Hoffman, I., Van Steen, K., Vermeire, S., and Rutgeerts, P. 2009b. Mucosal healing predicts long-term outcome of maintenance therapy with infliximab in Crohn's disease. Inflamm Bowel Dis 15(9): 1295-1301. doi: 10.1002/ibd.20927.

Schreiber, S., Khaliq-Kareemi, M., Lawrance, I.C., Thomsen, O.O., Hanauer, S.B., McColm, J., Bloomfield, R., Sandborn, W.J., and Investigators, P.S. 2007. Maintenance therapy with certolizumab pegol for Crohn's disease. N Engl J Med 357(3): 239-250. doi: 10.1056/NEJMoa062897.

Solberg, I.C., Vatn, M.H., Hoie, O., Stray, N., Sauar, J., Jahnsen, J., Moum, B., Lygren, I., and Group, I.S. 2007. Clinical course in Crohn's disease: results of a Norwegian population-based ten-year follow-up study. Clin Gastroenterol Hepatol 5(12): 1430-1438. doi: 10.1016/j.cgh.2007.09.002.

Steenholdt, C., Molazahi, A., Ainsworth, M.A., Brynskov, J., Ostergaard Thomsen, O., and Seidelin, J.B. 2012. Outcome after discontinuation of infliximab in patients with inflammatory bowel disease in clinical remission: an observational Danish single center study. Scand J Gastroenterol 47(5): 518-527. doi: 10.3109/00365521.2012.660541.

Summers, R.W., Switz, D.M., Sessions, J.T., Jr., Becktel, J.M., Best, W.R., Kern, F., Jr., and Singleton, J.W. 1979. National Cooperative Crohn's Disease Study: results of drug treatment. Gastroenterology 77(4 Pt 2): 847-869.

Sutherland, L.R., Martin, F., Bailey, R.J., Fedorak, R.N., Poleski, M., Dallaire, C., Rossman, R., Saibil, F., and Lariviere, L. 1997. A randomized, placebo-controlled, double-blind trial of mesalamine in the maintenance of remission of Crohn's disease. The Canadian Mesalamine for Remission of Crohn's Disease Study Group. Gastroenterology 112(4): 1069-1077. 
Thomson, A.B., Wright, J.P., Vatn, M., Bailey, R.J., Rachmilewitz, D., Adler, M., and Wilson-Lynch, K.A. 1995. Mesalazine (Mesasal/Claversal) 1.5 g b.d. vs. placebo in the maintenance of remission of patients with Crohn's disease. Aliment Pharmacol Ther 9(6): 673-683.

Togawa, J., Nagase, H., Tanaka, K., Inamori, M., Umezawa, T., Nakajima, A., Naito, M., Sato, S., Saito, T., and Sekihara, H. 2002. Lactoferrin reduces colitis in rats via modulation of the immune system and correction of cytokine imbalance. Am J Physiol Gastrointest Liver Physiol 283(1): G187-195. doi: 10.1152/ajpgi.00331.2001.

Treton, X., Bouhnik, Y., Mary, J.Y., Colombel, J.F., Duclos, B., Soule, J.C., Lerebours, E., Cosnes, J., Lemann, M., and Groupe D'Etude Therapeutique Des Affections Inflammatoires Du Tube, D. 2009. Azathioprine withdrawal in patients with Crohn's disease maintained on prolonged remission: a high risk of relapse. Clin Gastroenterol Hepatol 7(1): 80-85. doi: 10.1016/j.cgh.2008.08.028.

Troost, F.J., Saris, W.H., and Brummer, R.J. 2002. Orally ingested human lactoferrin is digested and secreted in the upper gastrointestinal tract in vivo in women with ileostomies. The Journal of nutrition 132(9): 2597-2600.

Turner, K., Genta, R.M., Lujan, G., Robiou, C., and Sonnenberg, A. 2014. Significance of the epithelioid granuloma in biopsies of Crohn's colitis. Inflamm Bowel Dis 20(12): 2271-2275. doi: 10.1097/MIB.0000000000000196.

Ueno, H., Sato, T., Yamamoto, S., Tanaka, K., Ohkawa, S., Takagi, H., Yokosuka, O., Furuse, J., Saito, H., Sawaki, A., Kasugai, H., Osaki, Y., Fujiyama, S., Sato, K., Wakabayashi, K., and Okusaka, T. 2006. Randomized, double-blind, placebocontrolled trial of bovine lactoferrin in patients with chronic hepatitis C. Cancer Sci 97(10): 1105-1110. doi: 10.1111/j.1349-7006.2006.00274.x.

Vilien, M., Dahlerup, J.F., Munck, L.K., Norregaard, P., Gronbaek, K., and Fallingborg, J. 2004. Randomized controlled azathioprine withdrawal after more than two years treatment in Crohn's disease: increased relapse rate the following year. Aliment Pharmacol Ther 19(11): 1147-1152. doi: 10.1111/j.1365-2036.2004.01944.x.

Vora, P., Youdim, A., Thomas, L.S., Fukata, M., Tesfay, S.Y., Lukasek, K., Michelsen, K.S., Wada, A., Hirayama, T., Arditi, M., and Abreu, M.T. 2004. Beta-defensin-2 expression is regulated by TLR signaling in intestinal epithelial cells. J Immunol 173(9): 5398-5405.

Walker, T.R., Land, M.L., Kartashov, A., Saslowsky, T.M., Lyerly, D.M., Boone, J.H., and Rufo, P.A. 2007. Fecal lactoferrin is a sensitive and specific marker of disease activity in children and young adults with inflammatory bowel disease. J Pediatr Gastroenterol Nutr 44(4): 414-422. doi: 10.1097/MPG.0b013e3180308d8e.

Waugh, A.W., Garg, S., Matic, K., Gramlich, L., Wong, C., Sadowski, D.C., Millan, M., Bailey, R., Todoruk, D., Cherry, R., Teshima, C.W., Dieleman, L., and Fedorak, R.N. 2010. Maintenance of clinical benefit in Crohn's disease patients after discontinuation of infliximab: long-term follow-up of a single centre cohort. Aliment Pharmacol Ther 32(9): 1129-1134. doi: 10.1111/j.1365-2036.2010.04446.x.

Wehkamp, J., Koslowski, M., Wang, G., and Stange, E.F. 2008. Barrier dysfunction due to distinct defensin deficiencies in small intestinal and colonic Crohn's disease. 
Mucosal Immunol 1 Suppl 1: S67-74. doi: 10.1038/mi.2008.48.

Wehkamp, J., Schmid, M., Fellermann, K., and Stange, E.F. 2005. Defensin deficiency, intestinal microbes, and the clinical phenotypes of Crohn's disease. J Leukoc Biol 77(4): 460-465. doi: 10.1189/jlb.0904543.

Wehkamp, J., and Stange, E.F. 2006. A new look at Crohn's disease: breakdown of the mucosal antibacterial defense. Ann N Y Acad Sci 1072: 321-331. doi: 10.1196/annals. 1326.030 .

Wells, J.M., Rossi, O., Meijerink, M., and van Baarlen, P. 2011. Epithelial crosstalk at the microbiota-mucosal interface. Proc Natl Acad Sci U S A 108 Suppl 1: 4607-4614. doi: 10.1073/pnas.1000092107.

Wenzl, H.H., Primas, C., Novacek, G., Teml, A., Offerlbauer-Ernst, A., Hogenauer, C., Vogelsang, H., Petritsch, W., and Reinisch, W. 2015. Withdrawal of long-term maintenance treatment with azathioprine tends to increase relapse risk in patients with Crohn's disease. Dig Dis Sci 60(5): 1414-1423. doi: 10.1007/s10620-014-3419-5.

Willoughby, J.M., Beckett, J., Kumar, P.J., and Dawson, A.M. 1971. Controlled trial of azathioprine in Crohn's disease. Lancet 2(7731): 944-947.

Yamamoto, T., Nakahigashi, M., Saniabadi, A.R., Iwata, T., Maruyama, Y., Umegae, S., and Matsumoto, K. 2007. Impacts of long-term enteral nutrition on clinical and endoscopic disease activities and mucosal cytokines during remission in patients with Crohn's disease: a prospective study. Inflamm Bowel Dis 13(12): 1493-1501. doi: 10.1002/ibd.20238.

Yamamoto, T., Umegae, S., and Matsumoto, K. 2006. Safety and clinical efficacy of granulocyte and monocyte adsorptive apheresis therapy for ulcerative colitis. World $\mathrm{J}$ Gastroenterol 12(4): 520-525. 
Table 1. Relapse rates in various studies testing maintenance of remission of Crohn's disease after medication withdrawal

\begin{tabular}{|c|c|c|c|c|c|c|c|c|c|c|c|}
\hline $\begin{array}{l}\text { Arbitrary } \\
\text { study No. }\end{array}$ & *Patients & $\begin{array}{l}\text { Outcome vs } \\
\text { location }\end{array}$ & $\begin{array}{l}\text { Time in remission } \\
\text { prior to medication } \\
\text { withdrawal }\end{array}$ & $\begin{array}{l}\text { First } 9 \\
\text { months }\end{array}$ & $\begin{array}{l}10 \text { to } 12 \\
\text { months }\end{array}$ & $\begin{array}{c}18 \\
\text { months }\end{array}$ & $\begin{array}{c}24 \\
\text { months }\end{array}$ & $\begin{array}{l}36 \text { to } 40 \\
\text { months }\end{array}$ & $\begin{array}{c}48 \\
\text { months }\end{array}$ & 5 years & \\
\hline 1 & 11 & NS & NR & 8 of 11 & & & & & & & (Willoughby, et al., 1971) \\
\hline $2 \mathrm{a}$ & 7 & NS & NR & 5 of 7 & & & & & & & (Brignola, et al., 1988) \\
\hline $2 b$ & 4 & NS & 4 weeks or more & 3 of 4 & & & & & & & (Brignola, et al., 1988) \\
\hline $2 \mathrm{c}$ & 5 & NS & 6 months or more & 4 of 5 & & & & & & & (Brignola, et al., 1988) \\
\hline $3 a$ & 13 & $\mathrm{IC} \& \mathrm{C}$ & 1 month or more & 7 of 13 & & & & & & & (Brignola, et al., 1992) \\
\hline $3 b$ & 9 & I & 1 month or more & 6 of 9 & & & & & & & (Brignola, et al., 1992) \\
\hline 4 & \#59 & NS & 20 - 3070 days & $31 \%$ & $52 \%$ & & & & & & (de Franchis, et al., 1997) \\
\hline 5 & 19 & NS & NR & & 17 of 19 & & & & & & (Candy, et al., 1995) \\
\hline 6 & 30 & NS & NR & & 21 of 30 & & & & & & (Modigliani, et al., 1996) \\
\hline 7 & 15 & NS & NR & & 8 of 15 & & & & & & (Vilien, et al., 2004) \\
\hline 8 & 18 & IC \& I & 3 weeks or more & & 17 of 18 & & & & & & (Bresci, et al., 1991) \\
\hline $9 \mathrm{a}$ & \#28 & $\mathrm{C}$ & 1 month or more & & $39 \%$ & & & & & & (IMSG, 1990) \\
\hline $9 b$ & $\# 43$ & IC & 1 month or more & & $36 \%$ & & & & & & (IMSG, 1990) \\
\hline $9 \mathrm{c}$ & \#34 & I & 1 month or more & & $31 \%$ & & & & & & (IMSG, 1990) \\
\hline 10 & \#161 & NS & 1 month or more & & $45 \%$ & & & & & & (Mahmud, et al., 2001) \\
\hline 11 & 20 & NS & Less than 8 weeks & & 13 of 20 & & & & & & (Yamamoto, et al., 2007) \\
\hline 12 & 95 & NS & 8 weeks & & 62 of 95 & & & & & & (Gross, et al., 1998) \\
\hline 13 & 1 & NS & Less than 1 year & & 0 of 1 & & & & & & (Lennard-Jones, 1977) \\
\hline $14 \mathrm{a}$ & 11 & $\mathrm{C}$ & 3 months to 2 years & & 6 of 11 & & & & & & (Prantera, et al., 1992) \\
\hline $14 \mathrm{~b}$ & 18 & IC & 3 months to 2 years & & 9 of 18 & & & & & & (Prantera, et al., 1992) \\
\hline $14 \mathrm{c}$ & 32 & I & 3 months to 2 years & & 17 of 32 & & & & & & (Prantera, et al., 1992) \\
\hline 15 & 36 & NS & 16 weeks or more & & 22 of 36 & & & & & & (Feagan, et al., 2000) \\
\hline 16 & 31 & NS & 6 months or more & & 15 of 27 & & & & & & (Arber, et al., 1995) \\
\hline $17 \mathrm{a}$ & 50 & IC \& C & less than 18 months & & 28 of 50 & & & & & & (Thomson, et al., 1995) \\
\hline $17 b$ & 21 & I & less than 18 months & & 10 of 21 & & & & & & (Thomson, et al., 1995) \\
\hline $18 \mathrm{a}$ & 64 & IC \& C & less than 18 months & & 26 of 64 & & & & & & (Sutherland, et al., 1997) \\
\hline $18 \mathrm{~b}$ & 63 & I & less than 18 months & & 21 of 63 & & & & & & (Sutherland, et al., 1997) \\
\hline $18 \mathrm{c}$ & 93 & NS & less than 18 months & & 39 of 93 & & & & & & (Sutherland, et al., 1997) \\
\hline
\end{tabular}




\begin{tabular}{|c|c|c|c|c|c|c|c|c|c|}
\hline $18 \mathrm{~d}$ & 35 & NS & less than 18 months & 8 of 35 & & & & & (Sutherland, et al., 1997) \\
\hline 19 & 110 & IC \& C & $\mathrm{NR}$ & & & & & & (Landi, et al., 1992) \\
\hline 20 & 40 & NS & 42 months or more & & & & & & (Lemann, et al., 2005) \\
\hline 21a & \#33 & NS & Less than 3 months & $68 \%$ & $71 \%$ & & & & (Gendre, et al., 1993) \\
\hline $21 \mathrm{~b}$ & \#48 & NS & 3 months to 2 years & $22 \%$ & $42 \%$ & & & & (Gendre, et al., 1993) \\
\hline 22 & 101,57 & NS & $1-2$ years or less & 36 of 101 & 34 of 57 & & & & (Summers, et al., 1979) \\
\hline $23 \mathrm{a}$ & 7 & $\mathrm{C}$ & 12 months or more & & 0 of 7 & & & & (Wenzl, et al., 2015) \\
\hline $23 b$ & 14 & IC & 12 months or more & & 7 of 14 & & & & (Wenzl, et al., 2015) \\
\hline $23 \mathrm{c}$ & 5 & I & 12 months or more & & 1 of 5 & & & & (Wenzl, et al., 2015) \\
\hline 24 & $\S$ & $\S$ & $\S$ & & $\S \sim 65 \%$ & & & & (Malchow, et al., 1984) \\
\hline 25 & $\# 10$ & NS & NR & & & $50 \%$ & & & (Nyman, et al., 1985) \\
\hline 26 & \#222 & DNI, NS & NR & $\dagger 37 \%$ & $\dagger 56 \%$ & $\dagger 66 \%$ & $\dagger 72 \%$ & $\dagger 75 \%$ & (Fraser, et al., 2002) \\
\hline 27 & \#66 & NS & 42 months or more & $14 \%$ & $53 \%$ & & & $63 \%$ & (Treton, et al., 2009) \\
\hline 28 & \#42 & NS & 6 to 93 months & $38 \%$ & & $61 \%$ & & $75 \%$ & (Bouhnik, et al., 1996) \\
\hline
\end{tabular}

* , \#: *Patients reaching the trial end-point, if given; otherwise, \# the number of patients used for statistical analysis and calculation of relapse rates.

C: Colitis (Crohn's disease of the colon); IC: Ileocolitis (Crohn's disease of the ileum + Colon); I: Ileitis (Crohn's disease of the ileum);

NS: The outcome of patients with colitis, ileocolitis, and/or ileitis was not specified.

NR: These patients were in medically induced remission. The time spent in remission prior to medication withdrawal was not reported.

DNI: Data concerning the number of patients with colitis, ileocolitis, and/or ileitis was not included

Study 2: While the CDAIs of the patients enrolled in this study was below 150, other laboratory parameters suggested that these patients were at high risk of relapse.

Study 4: Steering committee terminated the study at the time of interim analysis: $50 \%$ of the planned patients had been enrolled and followed for 1 year.

Mean duration of remission prior to enrolment was 592 days.

Study 5: Data shown is from Phase 2 of this study, which compared azathioprine alone vs. placebo in the maintenance of remission induced in phase 1.

Study 7: These patients were not treated surgically.

Study 8: The single patient who did not experience a relapse during the first year of the study remained in remission until the end of the follow-up period of 3 years.

Study 10: Mean duration of remission prior to enrolment was 22 months.

Study 11: This patient was not treated surgically.

Study16: This study may have included patients in spontaneous remission.

Study 17a: Of 105 patients, 47 patients were withdrawn from the study due to adverse events or insufficient therapeutic effect. Relapses may be under reported.

Study 17b: Of 43 patients, 14 patients were withdrawn from the study due to adverse events or insufficient therapeutic effect. Relapses rate may be under reported. 
Study 18a,b: The location of one CD case was unknown.

Study 18c: Patients stratified by type of remission: Remission in these patients was medically induced.

Study 18d: Patients stratified by type of remission: Remission in these patients was surgically induced.

Study 19: This study had 3 groups of patients. (A) Patients in clinical but not endoscopic remission started steroid tapering at the beginning of the study. (B) Patients in clinical but not endoscopic remission continued prednisolone treatment for 5 more weeks before starting steroid tapering. (C) Patients in clinical and endoscopic remission. Group $\mathrm{C}$ patients started steroid tapering at the beginning of the study. The remission rates in the 3 groups was not significantly different.

Study 22: Data shown is from part II of this study, which was composed of patients who had had active disease within the previous 2 years but were in medically induced remission at the time of entry into the study and patients who were in surgically induced remission within 1 year of entry into the study .

Study 23: The patients in this study had continuous azathioprine therapy for 4 years or more.

Study 24: $\S$ Specific data for the parameters in Table 1 are not reported. The life-table analysis based on failure and relapse of patients in remission at trial entry is shown in Fig. 6 of the report, however, specific data is not reported.

Study 26: $\dagger$ This study reports the proportion of Crohn's disease and ulcerative colitis patients in remission at 12 months $(0.63), 24$ months $(0.44), 36$ months $(0.34), 48$ months (0.28), and 60 months $(0.25)$ after stopping azathioprine, and that 63 of the 79 Crohn's disease patients experienced at least one relapse during the follow-up period. Cox regression analysis of the proportion of patients in remission was identical for Crohn's disease and ulcerative colitis patients.

The study reports that for Crohn's disease, colonic disease favoured remission, however, data supporting this conclusion was not included in the report. 
Table 2. Relapse rates in various studies testing maintenance of remission of Crohn's disease after discontinuation of anti-TNF $\alpha$ antibody therapy

\begin{tabular}{|c|c|c|c|c|c|c|c|c|c|c|c|c|}
\hline $\begin{array}{l}\text { Arbitrary } \\
\text { study No. }\end{array}$ & Patients & $\begin{array}{l}\text { Concomitant } \\
\text { medication }\end{array}$ & $\begin{array}{l}\text { Within } \\
1 \text { year }\end{array}$ & $\begin{array}{l}\text { Within } \\
1.5 \text { years }\end{array}$ & $\begin{array}{c}2 \\
\text { years }\end{array}$ & $\begin{array}{c}3 \\
\text { years }\end{array}$ & $\begin{array}{c}4 \\
\text { years }\end{array}$ & $\begin{array}{c}5 \\
\text { years }\end{array}$ & $\begin{array}{c}7 \\
\text { years }\end{array}$ & $\begin{array}{c}10 \\
\text { years }\end{array}$ & $\begin{array}{l}\text { Response rate after } \\
\text { restarting anti-TNF } \alpha \\
\text { antibody therapy }\end{array}$ & \\
\hline 1 & 22 & $32 \& 35$ & 18 of 22 & & & & & & & & $81 \%$ (8 weeks) & (Farkas, et al., 2014) \\
\hline 2 & 121 & $72 \& 103$ & $45 \%$ & & & & & & & & $\mathrm{NR}$ & (Molnar, et al., 2013) \\
\hline 3 & 55 & 55 & 17 of 55 & & & & & & & & NR & (Ampuero, et al., 2016) \\
\hline 4 & 17 & 16 & & 5 of 17 & & & & & & & 4 of 4 (12 months) & (Molander, et al., 2014) \\
\hline 5 & 115 & 115 & $44 \%$ & & $52 \%$ & & & & & & $38 \& 42$ of 43 & (Louis, et al., 2012) \\
\hline 6 & 110 & 92 & & & & & $50 \%$ & & & & $\mathrm{NR}$ & (Schnitzler, et al., 2009a) \\
\hline 7 & 48 & 35 & & $50 \%$ & & & & & $65 \%$ & & NR & (Waugh, et al., 2010) \\
\hline 8 & 53 & 46 & $39 \%$ & & $50 \%$ & & & & & $88 \%$ & 24 of 25 & (Steenholdt, et al., 2012) \\
\hline 9 & 100 & 95 & $4 \%$ & & $7 \%$ & $12 \%$ & $20 \%$ & $27 \%$ & & $48 \%$ & NR & (Papamichael, et al., 2015) \\
\hline
\end{tabular}

NR: The response of relapsed patients restarting TNF $\alpha$ antibody therapy was not reported.

Study 1: A total of 41 patients with Crohn's disease were followed. 32 of these patients were treated with steroids and 35 with azathioprine in addition to biological therapy. 22 patients followed were in clinical remission + mucosal remission.

Study 2: 72 patients were treated with steroids and 103 patients were treated with thiopurines in addition to biological therapy.

Study 3: Patients achieved remission within 6 months of receiving combined biological (IFX or adalimumab) + immunosuppressive therapy and remained in remission for at least 6 months. After at least 6 month of combined therapy, biological therapy was withdrawn and the patients continued with immunosuppressive therapy.

Study 4: Patients were in remission for 6 months or more. Follow-up time was 12-15 months

Study 5: Patients were in remission for 6 months or more. 38 of 43 patients were in remission and 42 of 43 had a clinical response after restarting TNF $\alpha$ antibody therapy.

Study 6: The median time in remission for the 110 patients was 47.3 months.

Study 7: $50 \%$ relapse rate at a median of 477 days.

Study 8: Concomitant immunosuppression therapy was not associated with relapse or prolonged remission.

Study 9: 100 patients were followed for a median of 9.7 years. At the end of the follow-up period 52 patients were in sustained clinical remission. The cumulative probabilities of sustained clinical remission (defined as maintaining disease remission until the end of the follow-up period) at 1,2,3,4, and 5 years was $96 \%, 93 \%, 88 \%, 79.9 \%$, and $72.8 \%$, respectively. 


\section{Figure Legends}

Figure 1. Colonoscopy on 20 Dec. 2011. Colonoscopic examination showed extensive erosive and ulcerative lesions from the colorectal region to the transverse colon. In addition, longitudinal ulceration was found in the descending and transverse colon. Blue arrows: Inflammatory polyps. White arrows: Erosion and ulceration.

Figure 2. Colonoscopy on 19 Jan. 2012. The second total colonoscopy showed mucosal healing from transverse colon to cecum, and improvement of ulcer lesions from sigmoid colon to transverse colon. The patient's CDAI was 415 . Blue arrows: Inflammatory polyps. White arrows: Erosion.

Figure 3. Colonoscopy on 23 Oct. 2015. The third colonoscopic examination showed almost complete mucosal healing. Blue arrows: Inflammatory polyp. 


\section{age 29 sibchemistry and Cell Biology :-}

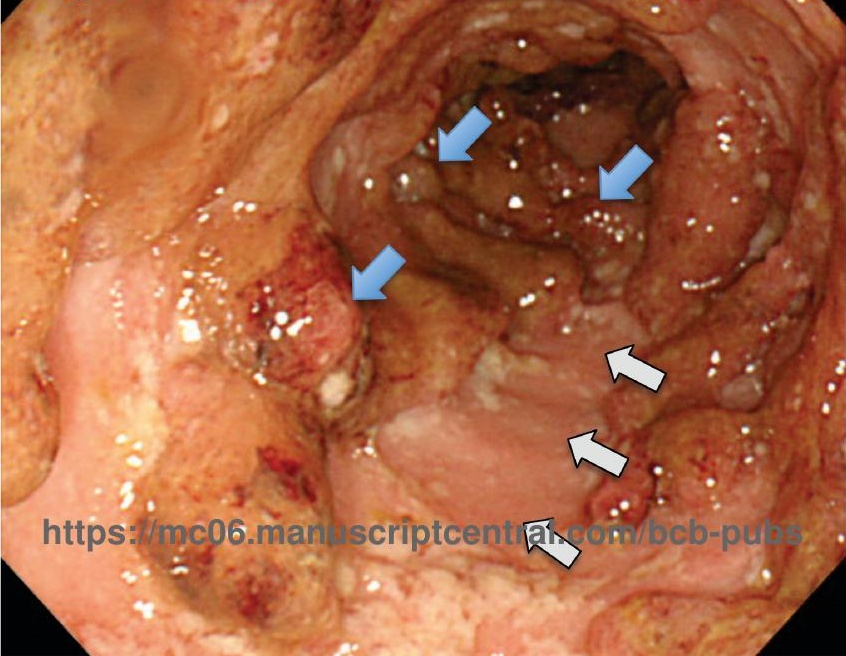




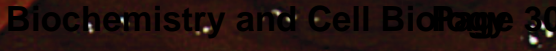
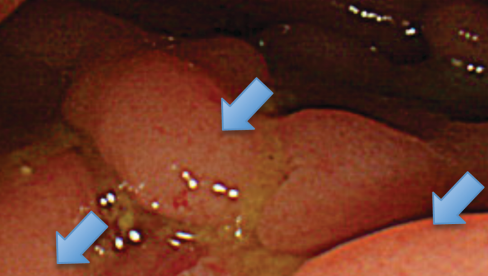

a

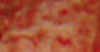

$+8$

$\infty$ 8

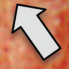

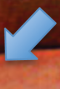

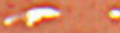

$+0$

002

$\therefore$

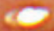

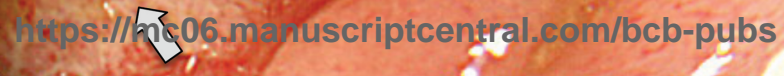


808

ge 3.1 đischemistry and Cell Biology

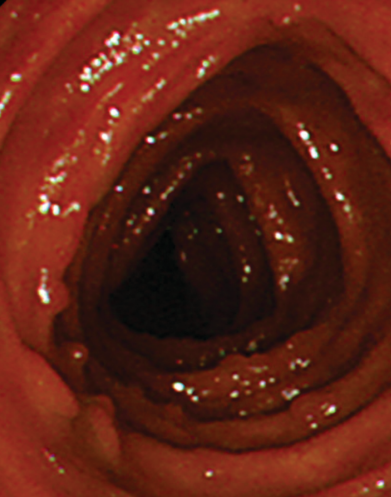

https://mc06.makne nintoentral.com/bcb-pubs

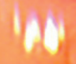

10 